Studia Anglica Posnaniensia 50/4, 2015

doi: 10.1515/stap-2015-0034

\title{
WADING THROUGH BLACK JADE IN MARIANNE MOORE'S SUNKEN CATHEDRAL: THE MODERNIST SEA POEM AS A DELEUZIAN FOLD
}

\author{
PAULINA AMBROŻY ${ }^{1}$
}

Faculty of English, Adam Mickiewicz University in Poznań

\begin{abstract}
The study is a close reading of Moore's poem "The Fish" (1918) through the conceptual lens of Gilles Deleuze's trope of the fold, as explained in his influential 1988 study of Leibniz, The Fold: Leibniz and the Baroque. The purpose is to explore Moore's (neo)baroque sensibility and her peculiar penchant for Baroque tropes, images and forms. The Deleuzian concept of the fold, with its rich epistemological implications and broad cultural applicability as the universal trope of crisis, change, unrest and transience, helps to comprehend Moore's own philosophical and aesthetic concerns. The study, in accord with the interdiscursive character of the contemporary studies of modernism draws from art history, philosophy, theory, literature, and visual arts, to uncover a strong Baroque undercurrent in the poet's polyphonic imagination. Seen in the light of Deleuze's fold, Moore's poem emerges as a quasi-Baroque ruin, a sunken cathedral-cumgraveyard, with a theatrical chiaroscuro lighting and folding and unfolding of sense, which both shelters and entombs the severely wounded modernist soul.
\end{abstract}

Keywords: Marianne Moore, Gilles Deleuze, Modernist poetry, Baroque, Neo-baroque, metaphysical poetry, the fold, word and image, the sea poem, poetry and art

In his 1988 study of Baroque art through the lens of Gottfried Leibniz's monadology, Gilles Deleuze posits the fold as one of the central metaphors of the aesthetic and philosophical practice of this period. "The Baroque", the French scholar argues,

1 Corresponding author: Paulina Ambroży (apaulina@wa.amu.edu.pl), Faculty of English, Adam Mickiewicz University, al. Niepodległości 4, 61-874 Poznań, Poland. 
does not refer to an essence, but rather to an operative function, to a trait. It endlessly creates folds. It does not invent the thing: there are all the folds that come from the Orient, Greek, Roman, Romanesque, Gothic, classical folds... But it twists and turns the folds, takes them to infinity, fold upon fold, fold after fold.

(Deleuze 1993 [1988]: 227) $)^{2}$

As pointed out by one his translators, Jonathan Strauss, Deleuze's definition of the fold is not conceptually rigorous, which allows for its broader application: the philosopher distinguishes between the organic pli and inorganic repli, both of which in French "have a primary meaning of 'fold' and are largely synonymous, although the form of the latter suggests an idea of repetition" (Strauss 1991, after Deleuze 1991: 227). For Deleuze, Baroque aesthetic explores the flexibility and absorptive inclusiveness of the figure, claiming the fold as both a material form ("coils of the matter") and abstract concept ("folds of the soul" or "the mental landscape") $(F, 11-13)$. The trope, in Deleuze's interpretation, convincingly fuses and confuses both the material and spiritual level, foregrounding such diverse and contradictory qualities as repetition and movement, seriality and flow, rhythm and fluctuation, elasticity and symmetry, spatiality and temporality, unfolding and concealment, unity and multiplicity, harmony and unrest, limit and excess. In the physical sense, those "plastic forces" of the fold, as Deleuze calls them after Leibnitz $(F, 8)$, inform the style of Baroque materials, objects, compositions, shapes, including draperies, tresses, fabrics, costumes, decorations, architecture, iconographies and even narratives. In the abstract sense, they represent the metaphysical imagination in a state of unrest - the complex, labyrinthine territories and mysteries of the Baroque mind and soul $(F, 3)$, with their capacity for perceiving and conceptualizing coherence, harmony, unity of movement as well as infinitude, discord, variation and transformation.

Seeing a broader cultural reach of the trope, the French philosopher observes that "[t]he fold has always existed in the arts; the character of the Baroque is one of carrying the fold to infinitude" $(F, 3)$. Based on the principle of excess and instability, the fold embodies the condition of crisis or the essential imbalance, the un-tuning and "trembling" of Baroque structures, whether architectural, philosophical, theological or cognitive. "The baroque", Heinrich Wölfflin argues in his influential study of Renaissance and Baroque styles, "never offers us perfection and fulfilment, or the static calm of 'being,' only the unrest of change and the tension of transience" (1966: 62). Similarly Umberto Eco (1989: 7 ), who in the Baroque form sees the beginning of the modern idea of the open work, foregrounds its dynamic nature: "it tends to indeterminacy of effect (in its play of solid and void, light and darkness, with its curvature, its broken surfac-

2 Gilles Deleuze (1993 [1988]), The Fold: Leibniz and the Baroque. (Trans. Tom Conley.) London: Athlone Press. Hereafter abbreviated as $F$. 
es, its widely diversified angles of inclination". Deleuze's fold embraces all of those qualities. Suggestive of the infinite movement which simultaneously obscures and unveils, blurring the boundaries between the exterior and the interior, surface and depth, nothingness and presence, the fold becomes a rich trope for addressing "the unrest of change", along with such diverse notions as the temporality, circumstantiality and (im)materiality of the world, as well as subjectivity, spirituality, memory, communication, and the issue of representation in art. According to William Egginton, the fold is attractive to Deleuze, because it undoes the Cartesian concepts of atomism and linearity, pointing to "the churning difference within the univocity of being" (2010: 21). ${ }^{3}$

Following Deleuze's broad application of the metaphor to diagnose not only the Baroque but also the condition of modernity, ${ }^{3}$ I wish to claim it, along with its rich implications, for the study of Marianne Moore's sea poem "The Fish", whose form as well as conceptual framework reveal interesting parallels between her notion of the landscape poem and the Deleuzian idea of the fold. The fold, as will be shown, can be treated as both an episteme, an organizing principle, a persistent figure and a larger metaphorical paradigm, through which Moore's visual and moral sensibility comes to the fore, revealing an undercurrent of neobaroque 4 thinking at the heart of her poetic practice. ${ }^{5}$

Such an analysis is further legitimized by Moore's genuine and life-long interest in the Baroque, documented both by her critics and biographers, who often point to her poems' strong affinity with the aesthetic and spiritual sensibil-

3 Deleuze uses the fold to talk about such diverse disciplines as city planning, music, calculus, the chaos theory, cinema, the history of physics, art, and many others.

$4 \quad$ Monika Kaup (2005: 87) thus explains the relationship between the historical Baroque and its critical revision - the neobaroque: "Recovered as neobaroque, the baroque, as a nonexclusive, decentering principle, joins, however self-consciously and awkwardly, contradictory impulses of the premodern and the modern, faith and reason, the scientific and the mythic, marking the crisis and outer limit of modernity. The neobaroque recovers the historical baroque's alternate, pre-Enlightenment modernity, a transitional, ex-centric modernity and alternate rationality not reducible to the quantifying rationality that gained ascendancy in the eighteenth century".

5 Elsewhere, I have employed the Derridian concept of metaphor-as-the-fold, explicated in his collection of essays entitled White Mythology, especially in "The retrait of metaphor", as a tool to read Moore's poetry. In the study, which contains a more comprehensive analysis of Moore's animal poems (including "The Fish", "A Jelly-fish" and "The Octopus"), I argue that Moore's penchant for metaphorical and conceptual folding is targeted at destabilizing our habits of cognition and discourse that consequently opens poetic language and our imagination to the unknown. Some of the references and conclusions presented there also inform the present analysis, as Derrida's and Deleuze's notions of the fold share a conceptual core and can be used to display the infinite interpretative potential of Moore's poem. However, my focus here is on Baroque visual and moral sensibility underlying Moore's imagination, whereas the book revolves around the problem of poetic language as a form of camouflage, wound and catastrophe of meaning (cf. Ambroży 2012: 87-99). 
ity of seventeenth-century literature as well as art. Thus, for instance, Scarlatti's compositions serve as emblems of "consistent inconsistencies" in her poem "The mind is an enchanting thing", while Bach's polyphonic music informs her later works - "Dream" and "Propriety". In her essay on Observations, Moore's first collection of poems (1924), Louise Bogan claims boldly that Moore "does not resemble certain seventeenth-century writers; she might be one of them" (Bogan 1970, after Merrin 1990: 15). As noted by Jeredith Merrin (1990: 6-7), the poet's books, reviews, letters and notes present her as an avid reader of meditative and religious prose and poetry of the Baroque, especially that of George Herbert and John Donne, as well as John Milton, Jeremy Taylor, Robert Burton, Francis Bacon, Sir Walter Raleigh, Richard Baxter, and their later follower, Gerard Manley Hopkins. The critic contends further that the poet often "praised and appraised writers of all periods in terms of the seventeenth century”, comparing Stein's The Making of Americans to John Bunyan's The Pilgrim's Progress, and Thomas Hardy to Sir Thomas Browne (Merrin 1990: 6-7). Francis Bacon appealed to her on account of his "pleasing defiances"; Edward Topsell's witty and emblematic Histoire of Foure-footed Beasts was a model and source for her animal poems (e.g. "Sea Unicorns", "Pangolin", "Jerboa"), while the Metaphysical Poets provided her with the paradigm of infusing scientific, naturalist and psychological observations with moral significance (Merrin 1990: 22-23). However, not only the moral content of seventeenth-century writing but also the form and tone of Baroque poems have proven a lasting guidance for Moore. The poet's emblematic imagination, shaped from her early childhood by her Protestant and devotedly religious family (her maternal grandfather and her brother were Presbyterian ministers), was greatly influenced by the seventeenth-century metaphysical conceit - a type of image-complex or extended metaphor which is conceptual rather than perceptual and which becomes a way of rendering the growth of moral insight as well as a deeper realization of the drama of human experience (Dalglish 1961: 5-6). If, as Jack Dalglish observes, metaphysical poetry is a response to the increasingly sensed "lack of coherence and certainty in the world in which [the poets] found themselves" (1961: i), the conceit - which frequently astounds by means of wit, paradox, extravagant humour and an ingenious collusion of incongruous imagery beyond accepted reference - becomes a perfect vehicle for dramatizing the anxieties of Baroque culture as well as the philosophy and aesthetics of modernism, which is marked by a similar awareness of crisis, brokenness of experience and loss of a stable epistemological ground. For seventeenth-century poets, who confronted a culture in crisis, ${ }^{6}$ the conceit often served to capture and balance

6 A comprehensive discussion of the Baroque as a culture in crisis can be found in José Antonio Maravall's Culture of the Baroque: Analysis of a Historical Structure (1986). 
the tension between spiritual and material reality, between intellect and emotion. This quality was admired by T.S. Eliot, as proved by his essay on Metaphysical poetry; ${ }^{7}$ Moore - for whom the mind was "an enchanting thing" and the world "was awash with morals"5 (Bishop 1980b: 94-95), and who valued paradoxical reasoning, wit, and ingenious imagery which hovers between the mimetic and symbolic - saw the metaphysical paradigm as a natural model, which remained a rich source of inspiration.

Her poem "The Fish", which is the focal text in the present analysis, is a good example of Moore's endorsement of metaphysical imagination and the aesthetic principles of the Baroque. Its dizzying wealth and forceful fusion of organic, optical and architectural tropes, the sustained dramatic tension between beauty and horror and above all, the complex structure and visual design of the fold as the organizing principle of the whole invite a reading informed by the philosophical and aesthetic ideas of the Baroque. "The Fish" is also undoubtedly among the most "theatrical" of Moore's poems, in which the operations of concealment and spectacle play a central role, while the poet's excess of veiling and "taste for folds" $(F, 43)$ - also in the sense of an infinite deferral of truth yields very interesting results. The trope, as I shall attempt to argue, serves the poet both as the conceptual principle and strategy with which she can approach, but, at the same time, protect the elusive and unrepresentable truths and anxieties of the human spirit, allowing her to talk about mortality and our longing for the absolute without violating their ultimate secrets. What is more, I shall also posit that the Baroque figure, especially as employed by the poet, suits well to convey the condition of the modernist mind which shares the Baroque need to comprehend the diversified and ever fluid "folds" of reality.

In The Fold: Leibniz and the Baroque, Deleuze draws our attention to the infinite movement of the folds in Baroque art, a movement which consists of two components: "the coils of matter, and the folds of the soul" $(F, 3)$. He argues further that "in the Baroque the soul entertains a complex relation with the body" (the philosopher is interested primarily in the communication between the two levels, finding it essential to the understanding of the Baroque mind). The world of the Baroque is thus "organized according to two opposing vectors: a sinking

$7 \quad$ As noted by Kaup and Zamora (2010b: 29), Eliot's review essay “The Metaphysical Poets" (1921) and his study of Andrew Marvell certainly helped to revive Baroque poetry, but the vogue for the Baroque was more widespread in the twenties. In Sor Juana, Octavio Paz sees its roots in the affinities between the baroque aesthetic sensibility and the avant-garde practice: "The coincidence between baroque and avant-garde poetics is not a question of influences but rather a question of an affinity operating as much in the sphere of the intellect as in sensibilities. The baroque poet hoped to astonish and astound; Apollinaire proposed exactly the same thing when he extolled surprise as one of the basic elements of poetry. The baroque poet attempts to discover the secret relationships among things, exactly as affirmed and practiced by Eliot and Wallace Stevens" (Paz 1988, after Kaup and Zamora 2010b: 29). 
downward and an upward pull" $(F, 28)$, symbolizing the spirit's entanglement in, and its need to escape from, the "coils of matter". Citing diverse art historians, theoreticians and critics of the Baroque, Deleuze distinguishes certain common architectural and visual elements which can be read as reflecting the relation between the spiritual and the material in the philosophical outlook of the seventeenth century. Among the most prominent stylistic qualities of Baroque architecture, suggestive of the spiritual unrest of the century and visible especially in church design, the philosopher mentions "the scission between the interior and exterior", between the façade and the indoors: excessive decoration which "threatens to explode the interior" through its infinite creases, swirls and folds. Further, he enumerates "the spontaneity of the interior and determination of the outside", where the outside expresses "nothing" but itself, while the interior "falls back on itself, remains sealed, tends to offer itself to its viewer as a 'jewel box' in which the absolute resides". The sense of unease is intensified further by the interplay of light and shadow, the famous Baroque chiaroscuro, mastered by Caravaggio and Georges de La Tour, among others $(F, 28-32)$. As observed by Wölfflin, whose findings Deleuze frequently cites in his study, the seventeenth century "found beauty in the darkness which swallows up the form" (Wölfflin 1950 [1932]: 197). This "picturesque lighting", in Wölfflin's words, "is a play of light which has been independent of the object", "irrational", "indeterminate", "unclear", and in which "figures coalesce with the general darkness, leaving us only 'an approximation'. Thus, the Baroque chiaroscuro breaks with classical use of light in landscape painting, based on clear contrasts of colour, and "creat[ing] a bond between objects, then, here and there" (Wölfflin 1950 [1932]: 202). In the Baroque, the colour is not finished; rather it "bleeds" and "becomes" (Wölfflin 1950 [1932]: 221). The effect is a striking illumination of represented objects, a dramatic confusion of light and shadow, which blurs contours and spaces, increasingly suggesting the "mystery which never quite unveils its face" (Wölfflin 1950 [1932]: 30, 221), the truth to be revealed only partially, or remaining halfhidden in the shadow, beyond the ultimate grasp.

The fold, so frequently used by Baroque artists as a decorative and expressive element in painting, sculpture and architecture, entails many of the qualities listed above: instability, multiplication and inconclusiveness of forms; oscillation between concealment and display; labyrinthine, mathematical seriality, coupled with dynamic motion which prevents the cohesion of the whole; and the arrested flow of light, swallowed up by creases and pleats in the fabric. Using the example of Bernini's Ecstasy of St. Theresa, Deleuze explains the significance of the fold, which goes far beyond the merely decorative: "In every instance folds of clothing acquire an autonomy and a fullness that are not simply decorative effects. They convey the intensity of a spiritual force exerted on the body, either to turn it upside down or to stand or raise it up over and again, but in every event to turn it 
inside out and to mold its inner surfaces" ( $F, 122$; emphasis original). This intriguing spatial trope, with its potential for discordant accord and spiritual probing, seems particularly suited to the study of Moore's poem "The Fish", as the folds of matter and language in this work both conceal and reveal the somewhat crumpled folds of the spirit. If we assume, after Deleuze, that "the fold of the world is the fan" $(F, 30)$, whose tiny apertures allow a glimpse of what is behind them as much as they screen the eyes and the other senses from the full view and comprehension of the soul's mysteries, then Moore's poem - which folds and unfolds like a fan (Moore uses the very metaphor in the second stanza) - uncovers, in its "pleasing defiances" in the manner of Bacon, a world full of scars, perforations, ruins and wounds which seem impossible to heal and which pull us into the fuscum subnigrum of the modernist mind.

Arguably, Moore designed her poem with a skill and vision that matches those of the best Baroque writers, artists and architects. As indicated above, its central figure - or conceit - is the powerful and striking metaphor of the "injured fan", whose opening and shutting lies at the heart of the poem's structural and thematic thrust. The movement of its folds and the subtle play of chiaroscu$r o$ in the consecutive stanzas discloses a strange subaquatic seascape with excessive and outlandish decorations of a distinctly Baroque flavour, which continuously "threaten to explode the interior" of the poem's careful, almost mathematical design. For Deleuze, in Baroque art "classical reason [is] toppled under the force of divergences, incompossibilities, discords, dissonances" $(F, 81)$. This undoing of classical reason is often realized through unresolved tensions between the visible and the invisible, the upward and downward visual vectors, as well as between the outside and the inside $(F, 27-29)$. In view of the above, Moore emerges as a rightful heiress of the Baroque practice, executing her complex poetic "folds" with a precision worthy of Bernini or Caravaggio.

Sensitized to the dramatic effect of blurring and shadowing, Moore constructs her bizarre seascape out of optical tropes which reveal a baroque travel of light, which appears and disappears among the edges and figurative pleats of the text. In this optical obstacle race, where the ruling principle is that of the defamiliarization and miscegenation of visual planes, language acts as the "sun / split like spun / glass", moving with "spotlight swiftness / into the crevices - in and out" (Moore 1967b: 30). ${ }^{8}$ Such understanding brings Moore close to the Baroque vision of representation, which assumes that the cultivation of cognitive and perceptual doubt - also through the multiplicity of tropes and metaphoric density as well as obscurity - signals not so much an emptiness as a possibility of experiencing the depth and complexity of being (Egginton 2010: 63).

8 All references to the poem come from this edition of Moore's Complete Poems and will henceforth be abbreviated as $M C P$. 
According to Deleuze, in the Baroque structure we can see the folds of matter which satisfy our senses and sustain either "our uneasiness, our lassitude, or our dullness of the spirit" $(F, 238)$, but we can read the folds of the spirit because they invite allegorical thinking. Similarly, in the openings or perforated creases of Moore's metaphorical "fan", the façade of her subaquatic structure can indeed be seen and examined, displaying the familiar constituents of a typical seascape: a cliff, waves, light travelling through crevices, fish, mussel shells, barnacles, jelly-fish, crabs and submarine toadstools. As noted by Linda Leavell (2013: 49-51) in her recent biography of Moore, the seascape in "The Fish" was constructed from the poet's memories of Monhegan - a rocky island and a fishing village ten miles off the coast of Maine where the Norcross family vacationed in the summer of 1904. Moore returned to the island in 1917 and 1929 and, in the critic's words, "tried repeatedly to capture the experience of Monhegan in words", using the place as "rich stimuli and "inspiration for much of her sea imagery" (Leavell 2013: 50, 51). However, in accord with Baroque sensibility, Moore transforms and distorts the familiar view and its rustic, picturesque beauty; in "The Fish", the scene is not well-lit but dimmed; and the reader is forced to "wade" through water as impermeable and dark as "black jade", with only occasional "shafts of light" illuminating the "rooms" and "folds" of this subaquatic "chapel".

The first structural fold takes the reader by surprise, appearing as early as the poem's opening lines, which form a "pleat" with the title. Skilfully embedded into the second line, the eponymous fish turn out to be bait, pulling us under, into the shimmering darkness of the sea:

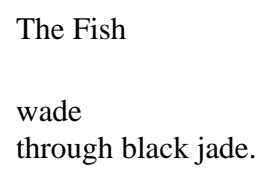

The next fold contains the most troubling and poignant simile in the poem - that of mussel shells "opening and shutting [themselves] like / an / injured fan":

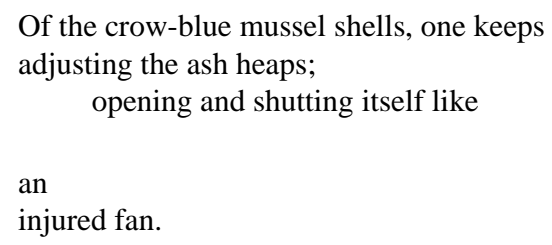


The metaphor signals and enacts the first perforation of the poem's external layer - the first hint at the Deleuzian legible behind the visible. The "injured" mussel shell-cum-fan, clearly an element of a baroque decoration-as-threat, simultaneously hides and displays, screens and releases the flow of light to enable at least partial access to the spiritual coils tangled between the swirls and folds of matter. The shell, cherished by Baroque artists both for its opulent, gracefully curved shape and pearly colouring, as well as a certain theatricality of display, is turned by Moore into an ominously crow-blue stage for a bizarre and dark spectacle. The images which subsequently emerge from the confusion of the picturesque and the terrifying, as Deleuze would have it, break out of their frames and fall back upon one another, producing an effect of "folds following folds" $(F, 237)$, stirring us out of our perceptual and spiritual ease. The Baroque mind, Egginton (2010: 74) claims, is forced to "experienc[e] both the convergences of knowledge and its dispersions, the bursting of the image onto the landscape of the unknown"; in Moore's poem, the familiar mussel shell seems to convey exactly that kind of knowledge - the chaos and horror "yet-tobe-synthetized" (Egginton 2010: 74), but now trapped between the possibility of representation and its failure.

In his explorations of seventeenth-century art, Deleuze draws our attention to the arrangement of light and darkness, "the new regime of light and color" ( $F$, 31 ), best exemplified in the period's painting and interior architectural designs. The upper portion of the painting, often taken up by a room without windows, is usually dark, "lined with black, the dark depth known in the painterly discourse as 'fuscum subnigrum' $(F, 28)$. The architectural metaphor best representing the relation between the soul and the external world, which Deleuze borrowed from Leibniz, along with its allegorical significance, is "a room in black marble, in which light enters only through orifices so well bent that nothing on the outside can be seen through them, yet they illuminate or color the décor of a pure inside" $(F, 28)$. In painting, on the other hand, the intensity of the darkness stems from the innovative technique used by both Caravaggio and Tintoretto, who replaced the white background employed before with a maroon one, "on which they placed the deepest shadows" $(F, 31-32)$. With the strong colours of the foregrounded elements, this technique results in a new sense of depth, a sensation that clarity is inseparable from obscurity and that all objects emerge from shadow and "shade off towards the shadows" $(F, 32)$. The light, argues Deleuze after Leibniz, "slides as though through a slit in the middle of shadows" and "plunges ceaselessly into shadow" $(F, 32)$. Moore uses light similarly: the strongly coloured elements, such as the rococo pink starfish and the mysterious turquoise bodies, emerge from the "black jade", "the absolute dark" $(F, 32)$, set up as the murky backdrop for the whole scene. Sunlight travels in quick waves between the crevices, in "submerged shafts" $(M C P, 32)$ so characteristic of the Baroque interior, illuminating the fractured components 
of the seascape. Moore strengthens the effect of spatial depth by using architectural metaphors to describe the movement of light and the fluctuating decorations of her "sunken cathedral": the sun is "split like spun glass", barnacles "encrust the side of the wave" and travel with "spotlight swiftness ... in and out" of the rock, "the defiant edifice" "lack[s] cornice". The uncanny apparitioning of the submarine ornaments "encrusted on the wave" - such as "crow-blue mussel shells", "pink rice-grains", "crabs like green lilies" or "inkbespattered jelly-fish" - is prompted by the optical tropes as well as by the movements of Moore's rhythmically folding and unfolding lines. In the manner of the Baroque fold, both the complex, multiply embedded lines and images collide and "slide each on the other" $(M C P, 32)$, creating hermeneutical openings and closures in the crevices and edges produced by those collisions.

Comparing Renaissance and Baroque styles, Wölfflin notes that the huge contrast between a linear and painterly style "corresponds to radically different interests in the world". "In the former case", the art historian argues, "it is the solid figure, in the latter, the changing appearance: in the former, the enduring form, measurable, finite; in the latter, the movement, the form in function; in the former, the thing in itself; in the latter, the thing in its relations" (Wölfflin 1966: 87-88). Similarly, Angela Ndalianis (2004: 152) claims that

\footnotetext{
the (neo-)baroque complicates classical spatial relations through the suggestion of the collapse of the representational frame. Rather than relying on static, stable view-points controlled and enclosed by the limits of the frame, the (neo-)baroque highlights the theatrical, spatially invasive nature of representation, dynamically engaging the audience in what Deleuze has characterized as 'architectures of vision'.
}

The result is "a continually shifting center"; "a complex dynamic motion" which enables "a flow between the inside and the outside" and creates an "open system" (Ndalianis 2004: 180).

In Moore's poem, this function is performed by the prosodic and graphic regime: an intensely rigid frame, which is however continually collapsing under the pressure of the eccentric reference. The equal number of syllables in each stanza - arranged in five lines and following the neat scheme of 1, 3, 9, 6, 8 serves as "the artificial grid", to borrow Hugh Kenner's (1987: 19) apt words or "the solid figure" which stabilizes the tensions and movement in the poem, while the bizarre imagery, diffused into the plurality of spatial planes, presses against and disrupts this logic to breaking point. The prosodic grid can also function as an equivalent of the Deleuzian façade of the Baroque church, whose integrity remains in "an almost schizophrenic tension" $(F, 33)$ with the folding and overwhelming interior, where "[t]he folds seem to take leave of their supports, cloth, granite, and cloud, to enter into infinite competition" $(F, 33)$. As Henri Focillon (1989 [1943]: 15) argues in The Life of Forms in Art, Baroque 
forms "break apart even as they grow", losing their contours and dispersing in shadows. In accord with the Baroque sensibility, the rigid scheme of Moore's "Fish" is similarly released and opened through the cracks, edges, and hatchet strokes, which truncate words and syllables, allowing the extended metaphor to leak and spill its meaning, and to shed some of the mysterious aura onto the hard lines and the chiselled façade of this seascape poem. The ambiguity resulting from the "spill" is Moore's determined choice suggesting the possibility of a truth whose content can be divulged not so much through mimetic approximations and rigidities of form but rather through obscuring mediations, porous structures and broken layers of language.

Just like the flamboyant style of seventeenth century architects, sculptors and painters, Moore's prosodic arrangement and surreal clusters of sliding, folding images entice equally strong sensuous and intellectual responses - creating, as Hall (1970: 48) puts it, "a sense of repeated blockage", with the lines "straining against an obstacle". This arrested movement (or "wading through black jade", as Moore herself would have it), reminiscent of Bernini's fluid sculptures that seem to be hiding and perpetuating either a mystery or a void, corresponds to and conditions the reader's progress through the poem: continuously obstructed by Moore's metaphorical "ink-bespattering" and "wounding" of her imagery. In this way, the poet further "dims the light" within her subaquatic edifice, thus sheltering her readers from full illumination and the comprehension of its bleeding folds, but also relentlessly stimulating their curiosity.

Considering the above obstacles, could we however venture behind the infinite slides and folds of Moore's design? Deleuze posits that the Baroque fold always hides or screens the "mental landscape", with "all textures of matter tending toward the higher point, a spiritual point, a spiritual form which envelops form, which holds it enveloped and which alone contains the secret of the material folds below" $(F, 246)$. Egginton (2010: 2$)$, in turn, emphasizes the theatrical aspect of the Baroque search for spiritual truth:

\footnotetext{
The Baroque puts the incorruptible truth of the world that underlies all ephemeral and deceptive appearances on center stage, making it the ultimate goal of all inquiry; in the same vein, however, the Baroque makes a theater out of truth, by incessantly demonstrating that truth can only ever be an effect of the appearances from which we seek to free it.
}

Marianne Moore, who wrote in a letter that "she do[es] not quite see how it is possible for one to live without religious faith, or ... without capacity for it" (Moore 1997: 34), often uses the formal texture of her poems as a stage on which to probe and convey the spiritual condition of her age. When followed closely, the tropes signal Moore's faith in the possibility of piercing the surface of appearance, of penetrating the jade-like water and offering us a glimpse of the truth that resides beneath it. Interestingly, the submerged light travelling in 
shafts through her poem unveils a sublime ruin, another trope favoured by Baroque artists, ${ }^{9}$ which in Moore's work is further haunted by mysterious "ash heaps" and inexplicable mutilations. The broken form allows for a quicker movement of life and light between the edges of Moore's ruin; at the same time, however, it perpetuates restlessness and confusion, opening the lines up for further egress of meaning, and thus denying us the comfort of clarity or closure. The final stanzas bring more of the bizarre "marks of abuse":

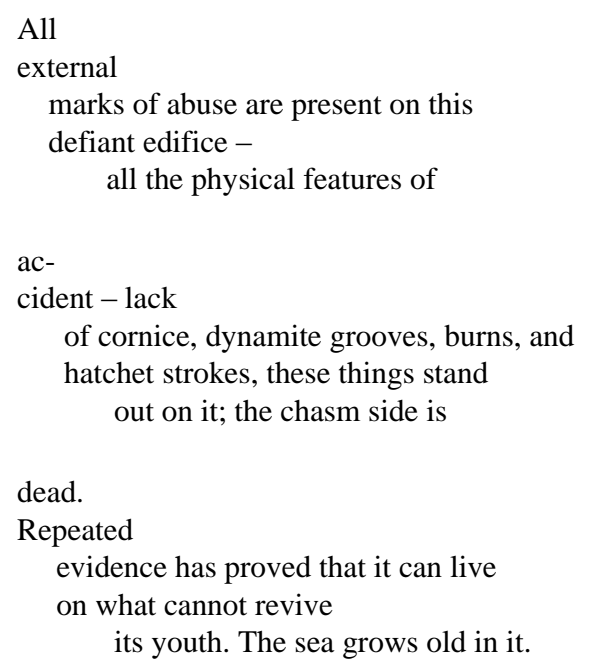

(MCP, 32)

If we hold onto the Baroque concept of the fold, where the coils of matter point to the coils of the spirit, and if we keep in mind the historical context in which Moore's poem originates, namely the aftermath of the Great War (1918), the spiritual content of "The Fish" becomes more comprehensible. ${ }^{10}$ The fish wade

$9 \quad$ Maravall (1986: 187) speaks of "the baroque preoccupation with the theme of ruins", which stemmed from a desire to "encounter the evidence of time" and from the rising historical consciousness. Ruins were also used to "study the structure of human work, and, therefore, the condition of the life of the human beings who had created it without being able to escape their own fleetingness". On a similar note, in his Trauerspiel Walter Benjamin (1998 [1963]: 182) observes that Baroque works are "consciously constructed ruins" that flaunt the seams of their artifice at their spectators and readers.

10 In his study of Moore, John M. Slatin discusses "The Fish" in the context of the Great War, arguing convincingly that it is an anti-war poem, depicting a sunken submarine wreck. For details of this argument see Slatin Savage's Romance: The Poetry of Marianne Moore (1986: 176-79). Guy Rotella (1991: 171) draws similar evidence from Moore's personal experience, observing that when Moore was writing the poem, her brother, who worked as a navy chaplain, had begun his duty at sea. The most recent biography of Linda Leavell (2013: 153-160), however, connects the dark and elegiac mood of the poem to Moore's disappointment with her brother Warner (often nicknamed "The Fish") who, during his sum- 
through the seascape of ruins, on the edge of a chasm where signs and memories of violence and death are still very fresh, and the wounds "stand out" on the mutilated edifice. The individual components of Moore's ruin are additionally charged with symbolic meaning: sea-shells and jade stones, as Mircea Eliade (1991 [1952]: 132-137) reminds us, are thought to be endowed with sacred and magical powers and have been used by various cultures as ornaments at funerary rites. Perforated shells, rice, pearls and nephrite stones were buried with corpses (in China, for example, they were placed in the mouth of the deceased) as symbols of death, spiritual rebirth and good after-life. By "encrusting" her subaquatic edifice with those funerary jewels, Moore subtly turns the landscape into a tomb and a site of memory. A further gloss to this peculiar vision of the sea can be found in another of Moore's poems, "A Grave", in which the sea is presented as "a collector, quick to return a rapacious look", who "has nothing to give but a well excavated grave" $(M C P, 49)$. The fishermen "lower nets, unconscious of the fact that they are desecrating a grave, / and row quickly away - the blades of the oars / moving together like the feet of water spiders as if there were / no such thing as death" $(M C P, 49)$. Both in "A Grave" and "The Fish", the sea leads us to the confrontation with the ultimate mystery - death. In "A Grave", man, positioned on the surface and afraid of sounding the darker depths of the sea, remains estranged from and oblivious of the subaquatic graveyard; in "The Fish", he is baited under and made a voyeur of the spectacle which turns into an uncanny, self-perpetuating funeral rite - a theater of truth about our mortality. However, the ultimate image of the devastated chasm that hosts the marine burial ground, with the enigmatic "it" around which the poem's quivering finale centers, does not unveil the ultimate truth; nor does it bring a final recognition of the poem's sense. Reinforced by the rigorous contour of Moore's poem, the "[r]epeated evidence" carries a promise of something solid and verifiable, but it has no clear complement and sounds strongly ominous: will there be more violence, more turquoise bodies, more "ash heaps" to fuel this drama? Embracing the aging sea, the final "it" thus becomes another confusing fold in our quest for meaning.

In her Marine Lover: Of Friedrich Nietzsche, a dialogue with a postHegelian philosophy and a feminist investigation of the elements, Luce Irigaray

mer trip to the family's favorite vacation site - Monhegan Island - met and proposed to his future wife, Constance Eustis, thus "betraying" the intimate and hitherto inseparable Mother-Daughter-Son circle. Warner himself, when confronted with the emotional landscape caused by his "betrayal" (after the announcement of the engagement, Moore described her feelings as being "seared"), admitted that his decision was "the hideous attack made upon precious 'Life' that [they] three have lived together". "My crime", he confessed to his sister, "is that while I would count it nothing to die for you, I have refused to live for you". The event, exacerbated by Warren's earlier decision to enlist, definitely ended an important period in Moore's life, bringing a deep sense of personal loss, deprivation, and abandonment. 
(1991 [1980]: 49) writes of the poly-optic power of the sea: "the sea shines with a myriad eyes. And none is given any privilege. Even here and now she undoes all perspective. Countless and shifting and merging her depths. And her allure is an icy shroud for the point of view". In his essay "Baroque curiosity", a Cuban Neobaroque writer and poet, José Lezama Lima claims that "the earth is Classical, the sea is Baroque" (Lima 1993 [1957], after Zamora and Kaup 2010b: 1). Moore's poem clearly partakes of this strange "Baroque" allure of the sea, teasing us with the fluidity and quiver of truth at each opening of her "fanstructure", only to destroy our certitude, as the poem leaves us with a spiritual and intellectual unease, worthy of her Baroque predecessors; an unease which matches the mental landscape of her entire generation. ${ }^{11}$ Taking our cue from Deleuze, we can read this poem-as-fold as the representation of the modernist mind, or - to borrow Costello's (1981: 74) apt words - "a theater for the mind to explore and solve questions it cannot confront in a human context", granting us "the privileged position of seeing what the fish cannot, a kind of displaced vision of our own mortality". "The Fish" thus becomes an elegiac piece, a poem of mourning for the broken world and for the wounded humanity, sealed off from spiritual resources. The modernist fan after all is severely "injured": the folds and coils of both matter and spirit are axed and perforated by the Great War and the post-Darwinian crisis of faith. The sea, which Whitman and Melville saw as specular and ready to return man's identity with either love or horror, in Moore's poem becomes a grave which bleeds with memories of violence, personal loss 12 and "grows old" among the ruins.

Moore's pleated lines capture the fleetingness, fluidity and violence of the natural and human world. Through the "axed" syntax and the capacious chasms of the sliding words and images, it dramatizes the ruin of language which cannot be put back together by an organic metaphor and thus fails to express the violent illuminations, inscriptions and injuries that pierce both the façade and the interior of the modernist psyche. Nevertheless, Moore holds on relentlessly to the formal scaffolding, the "envelope" of the fan-like structure in an attempt to prevent the sinking, leaking and dispersal of the wounded logos and spirit, in accord with the Deleuzian belief that "the envelope is the reason for the fold: what is folded is the included, the inherent" $(F, 22)$. The failure of the form to regulate the poem's shifting senses implies that the post-war condition produced a chasm between the world and the word which was perhaps too wide to bridge; yet, for Moore, "belief is stronger even than the struggle to survive" 28 (Moore

11 Monika Kaup (2012) sees a similar sensibility in the works of such modernists as T. S. Eliot, William Faulkner and Djuna Barnes. In her insightful study of T.S. Eliot's Waste Land, the critic convincingly argues that the poem can be read as a Neobaroque allegory (see especially her chapters "Neobaroque Eliot" and "Neobaroque in Djuna Barnes").

12 Here I mean Moore's severed relations with her brother Warren mentioned in footnote 10. 
1987: 402). Therefore, the pleats of her poem, which so skilfully entangle life and death, bringing to life the uncanny "turquoise bodies" and "ash heaps", continue to open and close to protect this belief, turning the sea into an envelope of the mysterious and the sacred, a submerged "coffin containing [the living ruins of] the absolute" $(F, 29)$.

Analysing Spanish Baroque poetry, Egginton (2010: 68) speaks of a "minor strategy of the Baroque", which "takes the promise of Being's transparency at its word, explores the folds of its architecture to their extremes, and finds there, in the place of its hoped for salvation, the desperation of an opacity without end". Moore's "The Fish" seems to use a similar strategy: it is not a poemwindow but an opaque grid full of folds and creases emerging from and withdrawing into the fuscum subnigrum of the modernist soul, whose obscurity indeed might be "without end". It is an envelope that ingeniously harbours and keeps alive, rather than represses, difficult memories and pain through the sublime beauty of the sub-aquatic imagery, based on dissonance and terror halfdispersed in aesthetic pleasure, the subtle chiaroscuro of optical metaphors, as well as the furling and unfurling lines. In the Baroque fabric, Deleuze observes, "knowledge is known only where it is folded" $(F, 49)$. In keeping with this sensibility, Moore shows that, as she argues elsewhere, "[f]eeling at its deepest ... tends to be inarticulate" (Moore 1987: 396). Thus, the seeming clarity of the graphic and prosodic form of "The Fish" collapses as it surges from the shadowy depths of the poem's inarticulate content $(F, 56)$, inviting us to get beneath its quivering folds with respect for the mysterious chasms, wounds and cinders of being which they so touchingly try to shelter.

Moore's "folding" and protective imagination, as exemplified by "The Fish", naturally raises more general questions about the significance of the Baroque strategy of representation for the poet's entire oeuvre, as well as its applicability for the study of modernist aesthetics. In the manner of Baroque art, the extended metaphor, which so beautifully connects and harmonizes the complex "folds" of the poet's imagination, works as an opaque canvas on which visible and often intricately "pleated" movements of images, words, and lines often break their frames and spill over, triggering anxious questions about the existence of invisible worlds and undecidable truths of life. "Truth is no Apollo / Belvedere, no formal thing. The wave may go over it if it likes", Moore contends in her poem "In the days of prismatic colour" $(M C P, 42)$. The wave which pushes against and threatens the "formal" Apollonian truth is like the Deleuzian fold pressing against the inflexible geometries and solidities of Renaissance art - the promise it carries is not clarity or closure but a perpetual flux and infinite undulation of the mind in what Wallace Stevens (1990 [1923]: 239) called "the act of finding". The Baroque troping and Moore's penchant for metaphoric chiaroscuro which competes in some of her poems with the imagist directness, precision and 
clarity, can be thus seen as representing that special alertness of her mind to the mystery of being deprived of Apollonian structures, linear perspectives and metaphysical certainties.

The fold may also signal a sense of artifice, contingency, ephemerality and fallibility of man-made frames and meanings vis-à-vis the modernist "fluent mundo" (Stevens 1990 [1923]: 407). Recognizing that contingency, Moore's seascape poem becomes an experience in which language plays more than a descriptive role in knowing, as it offers no fixed point for the perception and comprehension of the phenomena but rather an ever-shifting reality in which meaning is always an arduous process, with epistemological closure infinitely deferred. "Language is a special extension of power of seeing, inasmuch as it can make visible not only the already visible world, but through it the invisible world of relations and affinities" - the quote, which Moore borrowed from Howard Nemerov (1966: 11), captures the broader meaning of the poet's desire to relate diverse layers of experience in the folding and unfolding operations of language and the mind.

However, the cautiousness of Moore's method reflects also the spiritual anxieties of her age, marked, like the Baroque, by a profound metaphysical crisis and a growing realization of the unbridgeable gap between language and experience. In such poems as "A Jelly-fish", "The Pangolin", "The Sycamore", "The Mind is an Enchanting Thing" "The Octopus", "The Steeple-jack" or "The Plumet Basilisk", Moore represents the mysteries of the spirit as necessarily caught in the material folds of earthly experience, in the palpable, observable textures of human life, which, however, offer only brief, imperfect and elusive glimpses of the reality beyond the visible. In "A Jelly-fish," for instance, the title animal becomes another "folded" text in which the interplay between visibility and invisibility as well as pulsating movements of the jelly-fish's anamorphous body, mimicked further through the fold-like arrangement of the poem's lines, indicate the impossibility of reaching the ultimate truth which resists signification. In "The Mind is an Enchanting Thing", in turn, Moore's shifting paradoxical images travel like a "glaze on a / katydid-wing/ subdivided by sun / till the nettings are legion" $(M C P, 124)$, undoing all our cognitive certainties and refusing to coalesce into an integrated pattern. In "The steeple-jack", a scenic Düreresque seascape, with "water etched / with waves as formal as the scales / on a fish" and the seagulls which "keep flying back and forth over the town clock" is threatened by "the whirlwind fife-and-drum of the storm" and a truly disquieting Baroque excess of "eight stranded whales" $(M C P, 5)$. Like in "The Fish", Moore allows the chiselled form and artifice of the painted scene to be disrupted by the invasion of uncanny and darkly mysterious elements which function as a counterpoint designed to challenge the stability of the picture's frame no longer capable of holding the modernist world-as-becoming. 
As argued by Heuving (1992: 27), "Modern art derealizes content, [but] it also makes that content available for re-presentation". The contrapuntal foldlike structure of Moore's works partakes of that tendency, also with a view of changing the reader's relationship with the re-presented experience. In the manner of Baroque art, the reader is forced to abandon his or her comfortable positions and adopt an eccentric perspective which calls for a more active relation with the poem. ${ }^{13}$ As noted by Rotella (1991: 166), Moore's stylistic and metaphoric stratagems are meant to keep us "between the absolute and the contingent, between the abstract and the specific, sight and insight." Following the poet into the folds of her Baroque imagery and idiosyncratic idiom, "[w]e are left with an awakened sense of something 'beyond' representation but with no direction by which to account for that experience" (Costello 1981: 137). As a result, we are more actively transformed by the rich and demanding experience of the poem in which language becomes not so much a medium but the very site of difficult knowledge and a fitting metaphor for modernist epistemology, teaching us to accept optical dispersals, anti-specularity, fluctuation, overabundance of forms and metaphorical "folds" as part of the cognitive experience of the decentered and fluid world.

13 Moore's critics often argue that this eccentricity and radical otherness of her idiom stems also from her ambiguous gender positioning. Jeanne Heuving (1992: 27), for instance, postulates that Moore's poetic strategies belong to "the art of gynesis" which questions the universality of languages and cognitive structures. "Moore", the critic observes, "or any woman writer, can never 'truly' express herself, and certainly not within a lyric tradition highly dependent on specular and symbolic forms of representation" (Heuving 1992: 29). Heuving situates Moore next to other female poets, such as Gertrude Stein, H.D., and Djuna Barnes, who, in the critic's words, "encountered the limitations of a language of 'masculine specular(ization)' and opted for 'a poetry which finally does not avoid, nor repeat, gender, but represents it" (Heuving 1992: 167). Moore's frequent adoption of Baroque aesthetics goes also against the classical sensibility and 'hard form' of her influential male contemporaries such as Eliot, Williams and Pound, showing a strong subversive strain at the heart of her practice. Interestingly, however, in her essay "The Feminist Poetics of Marianne Moore", Rachel Blau Du Plessis (1988: 10) sees Moore's idiosyncratic practice as difficult to classify in terms of clear gender loyalties; the critic reads her disfigurations of form and content as an "anti-feminine gesture" which renounces such "feminine" qualities as beauty, finish and perfection, but, at the same time, as a non-masculinist strategy which stems from her avoidance of authoritarian statements. 


\section{REFERENCES}

\section{PRIMARY SOURCES}

Moore, Marianne. 1967a. Complete poems. New York: The Macmillan Company.

Moore, Marianne. 1967b. The fish. In Marianne Moore, Complete poems, 32-33. New York: The Macmillam Company.

Moore, Marianne. 1997. The selected letters of Marianne Moore. (Edited by Bonnie Costello, Celeste Goodridge \& Cristanne Miller.) New York: Knopf.

Moore, Marianne. 1987. The complete prose of Marianne Moore. New York: Elisabeth Sifton Books.

\section{SECONDARY SOURCES}

Ambroży, Paulina. 2012. (Un)concealing the hedgehog: Modernist and postmodernist American poetry and contemporary critical theories. Poznań: Wydawnictwo UAM.

Benjamin, Walter. 1998 [1963]. The origin of German tragic drama. (Trans. John Osborne.) London \& New York: Verso.

Bishop, Elizabeth. 1980a. The complete poems. New York: Farrar, Straus \& Giroux.

Bishop, Elizabeth. 1980b. Invitation to Miss Marianne Moore. In Elizabeth Bishop, The complete poems, 94-95. New York: Farrar, Straus \& Giroux.

Bogan, Louise. 1970. American to her backbone. In Louise Bogan, Poets alphabet, 370-371. New York: McGraw Hill.

Bloom, Harold (ed.). 1987. Modern critical views: Marianne Moore. New York, New Haven \& Philadelphia: Chelsea House Publishers.

Conley, Tom. 1993. Foreword. In Gilles Deleuze, The fold, ix-xx. London: The Athlone Press.

Costello, Bonnie. 1981. Marianne Moore: Imaginary possessions. Cambridge, MA \& London: Harvard University Press.

Dalglish, Jack. 1961. Eight Metaphysical poets. Oxford, UK: Heinemann Educational Publishers.

DuPlessis, Rachel Blau. 1988. No more of the same: The feminist poetics of Marianne Moore. William Carlos Williams Review 14(1). 9-25.

Eco, Umberto. 1989. Open work. (Trans. Anna Cangoni.) Cambridge, MA: Harvard University Press.

Deleuze, Gilles. 1993 [1988]. The fold: Leibniz and the Baroque. (Trans. Tom Conley.) London: Athlone Press.

Deleuze, Gilles. 1991. The fold. (Trans. Jonathan Strauss.) Yale French Studies 80. 227-247.

Egginton, William. 2010. The theatre of truth: The ideology of (Neo)Baroque aesthetics. Stanford: Stanford University Press.

Eliade, Mircea. 1991 [1952]. Images and symbols: Studies in religious symbolism. Princeton, NJ: Princeton University Press.

Eliot, T.S. 1998 [1921]. The metaphysical poets. In T.S. Eliot, Selected Essays 1917-1932, 141150. San Diego, CA \& New York: Hartcourt, Brace \& Company.

Focillon, Henry. 1989 [1943]. The art of forms in art. (Trans. Charles Beecher Hogan and George Kubler.) New York: Zone.

Hall, Donald. 1970. Marianne Moore: The cage and the animal. New York: Pegasus.

Heuving, Jeanne. 1992. Omissions are not accidents: Gender in the art of Marianne Moore. Detroit: Wayne State University Press.

Irigaray, Luce. 1991 [1980]. Marine lover: Of Friedrich Nietzsche. (Trans. Gilliam C. Gill.) New York: Columbia University Press. 
Leavell, Linda. 2013. Holding on upside down: The life and work of Marianne Moore. New York: Farrar, Straus \& Giroux.

Lima, José Lezama. 1993 [1957]. La curiosidad baroqua. In Irlemar Chiampi (ed.), La expressión americana, 79-106. Mexico City: Fondo de Cultura Económica.

Kaup, Monika. 2012. Neobaroque in the Americas: Alternative modernities in literature, visual art and film. Charlottesville, VA: University of Virginia Press.

Kaup, Monika. 2005. Neobaroque in Djuna Barnes. Modernism/Modernity 12. 85-110.

Kenner, Hugh. 1987. The experience of the eye. In Harold Bloom (ed.), Modern critical views: Marianne Moore, 11-23. New York, New Haven \& Philadelphia: Chelsea House Publishers.

Maravall, José Antonio. 1986. Culture of the Baroque: Analysis of a historical structure. Manchester: Manchester University Press.

Merrin, Jeredith. 1990. An enabling humility: Marianne Moore, Elisabeth Bishop, and the uses of tradition. New Brunswick \& London: Rutgers University Press.

Moore, Marianne. 1966. Some answers to questions posed by Howard Nemerov. In Howard Nemerov (ed.), Poets on poetry, 8-16. New York: Basic Books.

Nemerov, Howard (ed.) 1966. Poets on poetry. New York: Basic Books.

Ndalianis, Angela. 2004. Neo-baroque aesthetic and contemporary entertainment. Cambridge, MA \& London: MIT Press.

Paz, Octavio. 1988. Sor Juana, or, the traps of faith. (Trans. Margaret Sayers Peden.) Cambridge, MA: The Belknap Press of Harvard University Press.

Rotella, Guy. 1991. Reading \& writing nature. The poetry of Robert Frost, Wallace Stevens, Marianne Moore, and Elizabeth Bishop. Boston: Northeastern University Press.

Slatin, John M. 1986. Savage's romance: The poetry of Marianne Moore. University Park: Pennsylvania State University Press.

Stevens, Wallace. 1990 [1923]. The collected poems. New York: Viking Press.

Strauss, Jonathan. 1991.Translator's note. In Gilles Deleuze, The Fold. (Trans. Jonathan Strauss.) Yale French Studies 80: 227-247.

Wölfflin, Heinrich. 1950 [1932]. Principles of art history: The problem of the development of style in later art. (Trans. M. D. Hottinger.) Mineola, NY: Dover Publications Inc.

Wölfflin, Heinrich. 1966. Renaissance and Baroque. (Trans. Kathrin Simon.) Ithaca: Cornell University Press.

Zamora Parkinson, Lois \& Monika Kaup (eds.). 2010a. Baroque New Worlds: Representation, transculturation, counterconquest. Durham \& London: Duke University Press.

Zamora Parkinson, Lois \& Monika Kaup. 2010b. Baroque, New World Baroque, Neobaroque. In Baroque New Worlds: Representation, transculturation, counterconquest, 1-40. Durham \& London: Duke University Press. 